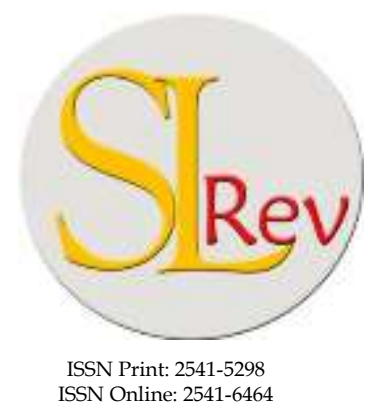

\section{SRIWIJAYA}

Editorial Office: Faculty of Law, Sriwijaya University, Jalan Srijaya Negara,

Palembang, South Sumatra 30139, Indonesia.

Phone: +62711-580063Fax: +62711-581179

E-mail: sriwijayalawreview@unsri.ac.id| sriwijayalawreview@gmail.com

Website: http://journal.fh.unsri.ac.id/index.php/sriwijayalawreview

\title{
Warehouse Receipt System Regulation in Indonesia: Is It Beneficial for Small Farmer?
}

\author{
Khoirul Hidayah, ${ }^{*}$ Iffaty Nasyi' ah, ${ }^{* *}$ and Jundiani ${ }^{* * *}$
}

\begin{abstract}
The regulation of Warehouse Receipt System (WRS) in Indonesia written in The Law No. 9 of 2011 concerning Amendment of WRS is expected to be useful and to facilitate farmers of WRS. However, in its practice, WRS in Indonesia was not yet able to improve the credit amount of banking with warehouse receipt as a guarantee. Malang Regency is one of the potential areas of farming products in East Java and once built WRS in 2012, so it is interesting to make this area as a research object in terms of reviewing WRS regulation in Indonesia. The issue is whether the purpose of establishing the law on WRS gave advantage and credit expediency, particularly for small farmers. This article is empirical legal research with a socio-juridical approach by describing the implementation of farm credit through WRS, describing the farmers' utilization of WRS in Malang Regency, then, analyzing it using regulation of warehouse receipt in Indonesia and the theory of legal effectiveness. Overall evaluation of WRS in the mentioned area shows that some parties, such as farmers, unit cooperation village, and local government, are at a loss. The evaluation result of WRS regulation implementation cannot realize the goals of the law on WRS; those are giving easy, affordable, and fast access to farmers in getting capital. The WRS cannot give advantage for small farmers. The policy of WRS in Indonesia has not yet been able to help farmers to challenge the competition in the free-trading market through ASEAN Economic Community. The researchers suggest that the WRS regulation must be made and integrated with farmer's policy so it can give advantage for small farmers.
\end{abstract}

Keywords: Benefit; Farmer; Indonesia; Regulation; Warehouse Receipt System.

\section{ARTICLE HISTORY:}

\section{DOI: 10.28946/sIrev.Vol3.Iss2.292.pp162-175}

Received: May 17, 2019;

Reviewed: Jul 6, 2019;

Accepted: Jul 28, 2019;

Published: Jul 31, 2019.

* Faculty of Sharia, Universitas Islam Negeri Maulana Malik Ibrahim, Indonesia, E-mail: khoirulhidayah55@gmail.com

** Faculty of Sharia, Universitas Islam Negeri Maulana Malik Ibrahim, Indonesia. E-mail: iffaty.nasyiah@gmail.com

**** Faculty of Sharia, Universitas Islam Negeri Maulana Malik Ibrahim, Indonesia, E-mail: jundideha@gmail.com.

\section{INTRODUCTION}

In 2003, Indonesia agreed to establish the ASEAN community in Economy, which is well-known as AEC (ASEAN Economic Community) and it is effectively valid in 2015. ASEAN charter and Blue Print signed in 2017 in Singapore state that ASEAN will be a single market with the basis of a single product which implies the flow of items, services, free skilled workers, investment, and a free capital flow among ASEAN countries. In facilitating the integration toward a single market and advancing product base, AEC 
then focuses on two specific sectors; those are priority integration sectors of food, agriculture, and forestry. One of the priority products of integration sector is agriculturalbased products.

In supporting the agricultural sectors to expand the market in ASEAN level, government's role is needed in making policy and the role of related stakeholder is also required to provide the financial resource. To improve agricultural productivity, one of the government's efforts is to issue a policy with the aims that it can help to provide fund for farmers. One of the policies issued is the legalization of Warehouse Receipt System (WRS) regulation is The Law No. 9 of 2006 concerning the Amendment of Warehouse Receipt System, which is a guarantee system in banking credits. WRS regulation is expected to help farmers in saving their harvest longer and help them in funding.

Many countries have applied the WRS pattern. Conference on Warehouse Receipt System (WRS) in Amsterdam in $9^{\text {th }}$ to $11^{\text {th }}$ of July, 2001 spotted some countries which successfully used WRS; they are Hungary, South Africa, Ghana, Kazakhstan, Russia, Zambia, Slovakia, Bulgaria, Mexico, Chechnya, Romania, Poland, and Turkey. ${ }^{1}$

The application of WRS is beneficial in that it can minimize the risk of agricultural product market, improve the food security system and the open access credit for villagers, and better the quality as well as transparency for warehouse industry through regulation and supervision. WRS is one of the instruments employed to stabilize the commod-

1 Mahanta, D, 2012, "Review of Warehouse Receipt as An Instrument for Financing in India," International Journal of Scientific \& Technology Research. 1 (9), pp42-45. ity price/inflation through trade delay. ${ }^{2}$ The regulation of WRS in Indonesia in The Law No. 9 of 2011 is anticipated to be beneficial and comfortable for WRS farmers, even though in its practice, WRS in Indonesia cannot improve the bank credit number with Warehouse Receipt guarantee. The research result of Listiani in Tuban showed that the employment of WRS was not optimal yet because the farmers did not fully understand about WRS and the establishment of supporting facilities was not at its finest. ${ }^{3}$ The implementation of WRS in Surakarta for six years could not attract most of the farmers to utilize WRS as the marketing alternative of their harvest and the funding of farming practice based on the instruction of The Law No. 9 of 2006 concerning Warehouse Receipt System. This implementation causes the relatively slow development of WRS, observed from the growth of number and value of Warehouse Receipt compared to its potential. ${ }^{4}$ The Deputy Governor of Bank Indonesia, Halim Alamsyah, has also informed that as a whole, the central bank noted the outstanding disbursement of bank credit to the new agricultural sector which is worth IDR 158.5 trillion or around $5 \%$ of the

2 Prof. Dr. Ir. Rina Oktaviani, M.Si, dkk., 2017, "Kajian Peningkatan Pemanfaatan Sistem Resi Gudang: Pilot Project di Kabupaten Kuningan, Jawa Barat (Komoditas Gabah) dan Konawe Selatan, Sulawesi Tenggara (Komoditas Kakao)," Buku BI 4, pvi.

3 Listiani, N., \& Haryotejo, B, 2013, "Implementasi Sistem Resi Gudang Pada Komoditi Jagung: Studi Kasus di Kabupaten Tuban, Provinsi Jawa Timur," Buletin Ilmiah Litbang, p197.

4 Suryani, E., Erwidodo, \& Anugerah, I. S., 2014, "Sistem Resi Gudang di Indonesia: Antara Harapan dan Kenyataan," Analisis Kebijakan Pertanian, 12 (1), p82. 
total of bank credit that is IDR 3.067,4 trillion in August 2013. ${ }^{5}$

East Java Province is a potential area of a good agricultural product. In 2009, the Ministry of Trade cooperated with East Java Local Government to build WRS in fulfilling the needs of the warehouse of an agricultural commodity. Malang Regency is one of the potential areas of agricultural product in East Java and once built WRS in 2012, so it is interesting to be the research object in reviewing WRS regulation in Indonesia. The issue is whether the law of WRS has fulfilled the legal benefit, specifically for small farmers.

\section{RESEARCH METHODS}

This article uses empirical legal research, namely a method of legal analysis using empirical facts taken from human's behavior, both verbally from an interview and real practice done by direct observation. ${ }^{6}$ This study also employs socio-juridical approach by describing the implementation of farm credit through WRS, describing the utilization of WRS by farmers in Malang Regency, and then analyzing it using the regulation of warehouse receipt in Indonesia, the theory of law effectiveness, the theory of legal benefit and its comparison with Malaysia.

The study uses primary and secondary data. The primary data are taken from the interviews with the chief of the sub-branch office of BCA in Tumpang, farmers' group, KUD (Eng.: Village Cooperative System) Padita Tumpang, KUD Koperasi Jasa Usaha Bersama Tiga Roda Pakis (the candidate of warehouse operator), and the chief of the

5 Infobank News.com. Asuransi Ternak Sapi diharap Dongkrak Kredit Pertanian. October 23, 2013.

6 Mukti Fajar dan Yulianto Achmad, Dualisme Penelitian Hukum Empiris \& Normatif, Yogyakarta: Pustaka Pelajar, 2010, p280.
Department of Industry and Trade of Malang Regency. The secondary data are achieved through documentation and literary investigation related to the guarantee of Warehouse Receipts such as books and scientific journals.

The technique of data collection is performed through interview and documentation. The data achieved from the in-depth interview are analyzed using a descriptivequalitative method by classifying, identifying, and so on. The analysis is performed by explaining the relations of the interview result with government's policy through the regulation and the law of WRS. The data obtained from field research are analyzed using Friedman's theory of legal system.

\section{ANALYSIS AND DISCUSSION}

The function of guarantee, according to Soebekti, is to give assurance to the creditors. ${ }^{7}$ To provide that assurance, a bank, therefore, is obligated to ask guarantee which is one of the requirements of credit guarantee as a basis of debtor's ability in paying back his/her credits. $^{8}$

WRS is a system related to the issue, the transfer, and the guarantee of Warehouse Receipts (WR). WR are documented, issued by warehouse operators as proof that specified commodities of stated quantity and quality, which have been deposited at particular locations by named depositors. ${ }^{9}$

7 Soebekti, Jaminan-Jaminan Untuk Pemberian Kredit Menurut Hukum Indonesia, Jakarta: Alumni, 1986, p20.

8 Djumhana, M, Hukum Perbankan di Indonesia, Bandung: Citra Aditya Bhakti, 2011, p57.

9 J. Coulter, G. Onumah, 2002, "The role of warehouse receipt systems in enhanced commodity marketing and rural livelihoods in Africa," Food Policy, 27 (2002), pp319-337. 
There are two kinds of Warehouse Receipt, namely, (1) the negotiable warehouse receipt which is a command or an instruction to submit the items to whomever in charge of that Warehouse Receipt; and (2) the nonnegotiable warehouse receipt which is a WR containing clauses that items in the warehouse can only be submitted to the one whose name written in the WR. WR can also be issued as a derivative WR in the form of a letter, and both can be traded in commodity stock. $^{10}$

Based on the law on WRS, Warehouse Receipt documents can be a guarantee in a bank or Lembaga Keuangan Non-Bank (Eng.: Non-Bank Financial Institution) to make credits. There are two types of credits which can be used by WR owner, namely commercial and subsidized loans. Commercial credit is a loan given to WR holder. Meanwhile, subsidized credit is a credit which got a subsidy of interest from the government with WR guarantee given by a bank to farmers, farmers' group, Gapoktan (Eng.: The Association of Farmers' Groups), and cooperatives. In WRS institution, there is a supervision board of WRS, warehouse operator, quality conformity assessment institution, registration center, including the harmonious relations of central and local governments, as well as the institution of WR guarantee. Through that guarantee institution, WR expects to gain greater trust from the entrepreneurs, namely WR holders, banks, and warehouse operator.

Article 1, the 2011 Law No. 9 elucidates that WR is an ownership proof document of items stored in warehouse issued by warehouse organizer. The employment of WR as a bank credit guarantee was already regulated

10 Wikipedia. 2019. Resi Gudang. Available From: http://id.wikipedia.org/wiki/ Resi gudang. in the law of WRS and was also regulated in The Regulation of Bank Indonesia No. 9 of 2007. The latter regulation mentions that there is an additional guarantee type, namely WR, which is tied with guarantee right of WR. The provision of Bank Indonesia enables farmers to use WR as the new credit guarantee besides land, house, and other assets. WR documents owned by farmers can be used to file the proposal of credit on working capital through banking institutions. WR is more accessible than other guarantees because it can be sold immediately without the role of the court or it has the title of parate executie.

Items in WRS, basically, include movable assets which can be stored in a certain period and be traded publicly. Generally, movable assets which are also objects of WR guarantee are products of agriculture, farm, or fishery. These kinds of products have particular characteristics, such as ${ }^{11}$

1. Their storage life is relatively shorter than non-agricultural products;

2. Perishable;

3. Bulky;

4. The storage process in the warehouse should be well-monitored since they are prone to any diseases.

5. The quality is highly influenced by the procedures done after the harvest especially during the drying and sorting process;

6. The price of agricultural products usually fluctuates and is influenced by the season.

According to the Ministry of Agriculture Regulation article 4 Number 33 of 2018 concerning the Third Amendment to the Ministry of Agriculture Regulation Number 37/M-

11 Iswi Hariani dan Serfianto, Resi Gudang Sebagai Jaminan Kredit dan Alat Perdaganan, Jakarta: Sinar Grafika, 2010, pp14-15. 
dag/Per/11/2011 concerning Goods that can be stored in a Warehouse in the Implementation of the WRS, the goods that can become a collateral or guarantee for Warehouse Receipt are grain, rice, corn, coffee, cocoa, pepper, rubber, seaweed, rattan, gambir salt, tea, copra, tin, onion, fish and nutmeg. The local government, commodity association and related institutions may recommend other goods to the list as long as they fulfill the requirements stated in article 3 of the Ministry of Trade Regulation Number 37/Mdag/Per/11/2011, namely: having a minimum three months' storage life; fulfilling certain quality standard; and reaching a minimum quantity.

The Implementation of Warehouse Receipt in Malang Regency

Warehouse Receipt System in Malang Regency has been starting since 2012 (Table 1) when the government issued The Law No.9 of 2011 on WRS. The local government of Malang Regency in 2012 built the WRS warehouses using Specific Allocation Fund (DAK). Disperindag (Eng.: Department of Industry and Trade) of Malang Regency aimed to develop WRS to improve the efficiency in agroindustry sector. The local government wanted the manufacturers to be able to upgrade the status of raw and half-raw materials into products that can be collateral.

In 2012, the government planned to develop WRS not only in sub-districts having high rice commodity potency but also in those having high productivity on WRS commodities. However, for the pilot project, it built a WRS warehouse in Tumpang subdistrict.

Built at the beginning of January 2012, the warehouse cost was covered by Specific Allocation Fund (DAK) of 2012 National
Budget for $\operatorname{Rp~5,142,310,000.00,~counterpart~}$ fund for $\operatorname{Rp~514,231,000.00~and~operational~}$ fund for $\mathrm{Rp}$ 257,115,500.00 from General Allocation Fund (DAU) of Malang Regency Local Budget. The area of the warehouse was $1,000 \mathrm{~m}^{2}$ on $4,707 \mathrm{~m}^{2}$ land of the government of Malang Regency. It was equipped with $500 \mathrm{~m}^{2}$ of drying floor, $240 \mathrm{~m}^{2}$ dryer box, and dryer with 20 tons capacity.

Since the warehouse was built in 2012, Disperindag tried to conduct socialization to farmers and to prepare cooperation with warehouse manager licensed from Bappebti or CoFTRA (Commodity Futures Trading Regulatory Agency). As the WRS requirement in article 23 (1) of the Law No. 9 of 2011 Concerning Warehouse Receipt System, the warehouse operator must have a legal entity and approval from the monitoring agency, namely Bappepti. Through the requirements, the local government tried to cooperate to assist warehouse managers in Malang Regency.

Table 1.

Data Implementation of Warehouse Receipt in Malang

\begin{tabular}{|c|c|c|c|c|}
\hline $\begin{array}{l}\text { Ye } \\
\text { ar }\end{array}$ & Users of WRS & $\begin{array}{l}\text { Warehouse } \\
\text { Manager }\end{array}$ & $\begin{array}{c}\text { Candidate } \\
\text { of } \\
\text { Warehouse } \\
\text { Manager }\end{array}$ & $\begin{array}{l}\text { To } \\
\text { tal } \\
\text { (to } \\
\text { n) }\end{array}$ \\
\hline $\begin{array}{l}20 \\
13\end{array}$ & $\begin{array}{l}3 \text { farmers (KJUB } \\
\text { Tiga Roda, } \\
\text { Kelompok Tani Sri } \\
\text { Rejeki, Koperasi } \\
\text { Sejahtera Bersama) }\end{array}$ & PT. Pertani & $\begin{array}{l}\text { Koperasi } \\
\text { Jasa Usaha } \\
\text { Bersama } \\
\text { Tiga Roda }\end{array}$ & $\begin{array}{l}14 \\
1.2\end{array}$ \\
\hline \multirow{2}{*}{$\begin{array}{l}20 \\
14\end{array}$} & \multirow{2}{*}{$\begin{array}{l}4 \text { farmers (Koperasi } \\
\text { Sejahtera Bersama) }\end{array}$} & PT. Pertani & $\begin{array}{l}\text { Koperasi } \\
\text { Mitra } \\
\text { Usaha }\end{array}$ & $\begin{array}{l}82 . \\
3\end{array}$ \\
\hline & & PT. Pertani & $\begin{array}{l}\text { Koperasi } \\
\text { Mitra } \\
\text { Usaha } \\
\end{array}$ & $\begin{array}{l}59 \\
4.5 \\
95 \\
\end{array}$ \\
\hline $\begin{array}{l}20 \\
15\end{array}$ & - & PT. Pertani & $\begin{array}{l}\text { Koperasi } \\
\text { Mitra } \\
\text { Usaha }\end{array}$ & - \\
\hline $\begin{array}{l}20 \\
16\end{array}$ & - & $\begin{array}{l}\text { PT. Bhanda } \\
\text { Gara Reksa } \\
\text { (BGR) }\end{array}$ & $\begin{array}{l}\text { Koperasi } \\
\text { Mitra } \\
\text { Usaha }\end{array}$ & $\begin{array}{l}20 . \\
07\end{array}$ \\
\hline $\begin{array}{l}20 \\
17\end{array}$ & - & $\begin{array}{l}\text { No } \\
\text { cooperation }\end{array}$ & - & - \\
\hline
\end{tabular}




\begin{tabular}{ll}
20 \\
$18-$ & PT. Pos \\
& Indonesia - \\
\hline
\end{tabular}

Source: Analysed from the primary source.

These (Table 1) are the efforts of the local government of Malang Regency in implementing WRS program: ${ }^{12}$

1. Conducting socialization to the farmers;

2. Cooperating with Bappepti licensedwarehouse operator and assisting them in Malang Regency. The local government works with PT. Pertani, PT. Bhanda Gara Reksa (BGR) and PT. Pos Indonesia;

3. Cooperating with banks since 2012, the local government only works with Bank Jatim and BNI; and

4. Supporting the budget using local budget annually for warehouse regulation cooperation and warehouse maintenance.

\section{The Effectiveness of WRS Implementation} in Malang Regency through WRS Regulation in Supporting Agricultural Sector Production toward AEC

To measure the effectiveness of warehouse receipt implementation, the researcher employed a fast, simple, and low-cost analysis in Law of WRS and Friedman's theory. The general elucidation of the Law No. 9 of 2011, states that WRS regulation was made to fulfill the effective and efficient principles in trading toward the global market and to give a simple and straightforward financing procedure. The following explanation describes whether the Law of WRS has fulfilled the principles of easy, low cost, and beneficial using an analysis of the implementation of WRS in Malang Regency.

12 Hasan Tuasikal, Chief of Trading Division of Disperindag Kabupaten Malang. Interview, October 26, 2018.

\section{Easy Principle}

The regulation of the warehouse receipt system is expected to ease farmers. However, normatively, the Law of WRS has not been able to provide easy access since it requires long and procedural steps. The steps of storing goods in the warehouse comprise goods quality test and the issuance of Warehouse Receipt in Bantul which takes 49 days, ${ }^{13}$ Indramayu and Subang Regency takes three days, ${ }^{14}$ Meanwhile, Malang Regency's target is seven days maximum until the credit is released. ${ }^{15}$ In reality, PT. Pertani took three weeks (21 days) and PT. BGR took one week (7 days) to wait for the credit to release.

According to farmers of Malang Regency, Micro Credit Program (KUR) provides easier access to credit than WRS. By having Kartu Tani (Farmer Card), they can access low-interest non-collateral credits from banks referred by the government (Bank Nasional Indonesia) by paying the loan after the harvest. The facility provides a maximum of 25 million rupiahs for noncollateral credit. The policy issued by the Ministry of Agricultural is not under WRS Program of Ministry of Trade. People tend to choose programs with easy access and procedure.

13 Achmad Fachruddin, Lestari Rahayu, 2017, "Evaluasi Prasyarat Keberhasilan Sistem Resi Gudang di Kabupaten Bantul," https://doi.org/ 10.18196/agr.3250.AGRARIS: Journal of Agribusiness and Rural Development Research. 3 (2), p105

14 Suryani, E., Erwidodo, \& Anugerah, I. S., 2014, "Sistem Resi Gudang di Indonesia: Antara Harapan dan Kenyataan," Analisis Kebijakan Pertanian, 12 (1), p80

15 Disperindag. March 2, 2016. Meeting Report SKPD About WRS Implementation in Malang Region. Malang. 


\section{Low-Cost Principle}

The implementation of WRS based on the Law of WRS offers a simple principle to help farmers in accessing credits. However, the aim of Law of WRS to provide solution for farmers in dealing with financing problem due to limited access and credit collateral is answered by another government program that is KUR in 2015 through the 2015 President Regulation No. 14 concerning Financing Policy Committee for Micro, Small, and Medium Enterprises (MSMEs) as amended by the 2015 President Regulation No. 19 concerning the 2015 Amendment of President Regulation No. 14 concerning Financing Policy Committee for Micro, Small, and Medium Enterprises (MSMEs) and the Guidelines of Micro Credit Program (KUR). The concept of KUR is a work capital financing/credit and investment for the individual debtor, institutions, a productive and feasible business group which have no or sufficient additional collateral. ${ }^{16}$ The target MSMEs and Cooperative, which can access KUR are those in productive sectors such as agriculture, fisheries and marine, industries, forestry, and saving and credit financial service. The distribution of KUR can be done directly. It means that MSME and Cooperative can directly access KUR in Branch Office or Sub-Branch Office of executive banks. ${ }^{17}$

KUR provides farmers a much simpler and cheaper offer, without spending more money on storage and transportation. The

16 The KUR concept which is offered by the government through the Coordinating Minister for Economic Affairs of the Republic of Indonesia as Chair of the Financing Policy Committee for Micro, Small and Medium Enterprises.

17 KUR. Available From: http://kur.ekon.go.id/maksud-dan-tujuan. (December 25, 2018). policy of Kartu Tani also provides farmers a low cost and non-collateral financing access. They can pay the credit after the harvest.

Koperasi Tiga Roda in Pakis Subdistrict, Malang Regency did not want to be warehouse manager candidate. It had to pay 5 million rupiahs for the maintenance of the warehouse (belongs to local government) even though they did not store their unhulled rice in the warehouse. The farmers also had to spend a lot of money. They were traumatized, and none of the Pakis farmers wanted to store their rice in a local government warehouse. ${ }^{18}$ WRS offered no solution to their problems. Instead of giving easier access, it offered a problematic and costly procedure.

\section{Beneficial Principle}

Law of WRS aims to give benefit to farmers, namely, to provide easy financing access and integrative marketing access. On the contrary, far from the expectation, it provides no advantage so far. Besides its limited warehouses, only one warehouse in Malang Regency, the minimum warehouse operator and also the existing KUR and Farmer Card prevent WRS to provide benefit to farmers. The new government policy through the Ministry of Trade and Coordinating Ministry of Economic Affairs is proven to give a better profit than WRS.

Besides using the principle of easy, low cost and benefit in Law of WRS to measure its effectiveness, the researcher also employed the law system theory of Lawrence Friedman to measure the implemented law effectiveness.

Friedman's theory measures the law effectiveness using three indicators, namely

18 Nanik, Chief of KUD Tiga Roda Kecamatan Pakis Kabupaten Malang, interview, February 4, 2019. 
law substance, structure and culture ${ }^{19}$. The following explanation describes some elements in measuring law effectiveness:

\section{Legal Substance}

The legal substance mentioned in this study comprises The 2006 Law No. 9 concerning Warehouse Receipt System and The Law No. 9 of 2011 concerning Amendment of Warehouse Receipt System. The warehouse receipt regulation has given protection to all parties. These are the flow of the warehouse receipt based on the WRS regulation:

a. Farmers store their goods in the warehouse owned or managed by the warehouse operator (who is licensed by Commodity Futures Trading Regulatory Agency)

b. The quality of products stored for warehouse receipt (such as grain and rice) were evaluated by Quality Conformity Assessment Body (Sucofindo, for instance)

c. Warehouse operator issues the warehouse receipt;

d. Farmers file credit to the Financing Institution;

e. Credit is in the process; the financing institution surveys goods stored in the storage

f. Credit guarantee provision is given by Indonesian Credit Guarantee State-Owned Companies

g. Verification and confirmation of the imposition of right guarantee is delivered to the Registration Center of Warehouse Receipt (PT. Kliring Berjangka Indonesia or $\mathrm{KBI})$

h. Right guarantee imposition registry is conducted by KBI.

19 Lawrence M. Friedman, Sistem Hukum Perspektif Ilmu Sosial, The Legal System: A Social Science Perspective, Bandung: Nusamedia, 2013, pp12-19.
Based on those stages, normatively, the warehouse receipt regulation is well performed, and it has provided legal protection to farmer or financing institution. The new regulation of the Law No. 9 no 2011 has regulated the guarantee institution for financing institution.

\section{Legal Structure}

To clarify the legal effectiveness, these are the evaluations of several parties involved in WRS comprising local government, Commodity Futures Trading Regulatory Agency (Bappepti), warehouse operator, financing institution, conformity assessment institution, quality assurance institute, and farmer cooperative. Based on the result of the interview conducted in the field, these are the explications regarding the institutional structure regulated in the regulation of WRS regulation:

\section{a. Local Government}

WRS program is made to provide ease for farmers in getting credit. The normative reason of local government's participation in the national WRS program is written in article 33 of The Law No. 9 of 2006 concerning Warehouse Receipt System that elaborates the role of Local Government in the Warehouse Receipt System fostering. It comprises the regional policymaking to speed up the implementation of the Warehouse Receipt System.

A case occurred in Surakarta where Warehouse Receipt System was not beneficial since the amount of investment spent, and the cost imposed on farmers, which is relatively lower, are imbalanced. The types of the commodity having a high potential to be inputted in the Warehouse Receipt System are paddy, corn, soy, and cassava. ${ }^{20}$ Through a national program, the

20 Primartantyo, U. (2012). Penerapan Resi Gudang di Solo Tak Menguntungkan. AVAILABLE From: 
central government has helped the local government to establish a warehouse using the Specific Allocation Fund. The local government has helped to reinforce the role of the people's economic agent. These agents are the cooperatives. In this case, the Malang Regency government has conducted assistance for the warehouse operator candidates. The local government has not undertaken a warehouse operator assistance in Malang Regency successfully. Every time Village Unit Cooperative assistance is conducted, it always failed.

\section{b. Warehouse Operator}

Warehouse operator is one of the parties involved in the establishment of WRS. The limited numbers of WRS in Indonesia become an obstacle in implementing WRS. A regulation will be able to be well performed as long as the structure supporting the regulation is well provided. The minimum numbers of warehouse operators cause either the government or farmers in WRS spent a significant amount of money. Local government must pay a big amount of money for warehouse operator candidates' assistance, and farmers must also spend transportation expense to go to the warehouse, which is limited in numbers, just like Malang regency which only has one warehouse.

Local government constructs a warehouse, warehouse operator candidates are assigned by the local government, and the local government join hands with the warehouse operators who have obtained the license from Commodity Futures Trading Regulatory Agency (Bappeti) to assist the warehouse operator candidates using

http://www.tempo.co/read/news/2012/12/19/09044 9267/Penerapan-Resi-Gudang-di-Solo-Tak Menguntungkan. (December 20. 2018). the professional honorarium expense issued by APBD (Regional Income and Expenditure Budget). The warehouse owned by the local government has been ignored since 2016 because no warehouse operator was capable of managing the warehouse.

\section{c. Banking}

In its practice, not all of the banking institutions have put their trust to WRS as credit guarantee/collateral. They will use WRS if credit guarantee institute exists. However, some banks still assume that WRS confronts a problem during goods transaction if a breach of contract happens (BCA). Banks still prefer movable and immovable goods as collaterals.

The latest data of Commodity Futures Trading Regulatory Agency in July 2017, showed the financing performed by both Banks and non-Banks since 2008 - the end of July 2017 was 299.1 billion, with 2480 receipts, commodity volume of $89.224,59$ ton, and a value of 506.5 billion rupiahs. The issued receipt comprises 14 types of WRS commodities, namely grain, rice, corn, coffee, cacao, pepper, rubber, seaweed, rattan, salt, gambier, tea, copra, and tin. $^{21}$ This fact can automatically strengthen the statement that several banking institutions haven't taken a role and given their trust to WRS.

There are two cases in Indramayu and Subang regencies. There are only a few banks in those regencies which accept WRS implementation since not all banks take the idea of implementing WRS in giving financing or credits. There is only one bank that agrees to provide credits to WRS that is BJB Bank. BJB bank has once faced

21 Bappebti/Mj1/190/XVI/2017/ September Edition, p9. 
with a problem, namely Non-Performing Credit. It happened when the goods stored inside the warehouse couldn't be sold yet on the due date. This case occurred during the last harvesting time in Haurgeulis warehouse in Indramayu. The goods couldn't be sold even after it was past the due date. This incident was triggered by the over-estimation of the Warehouse Receipt value of the stored grain. The estimation of grain stored in the warehouse is below the market price that comprises the accumulated expense spent covering drying cost, packaging expense, and transportation fee, ${ }^{22}$

\section{d. Quality Conformity Assessment Body}

Quality Conformity Assessment Body becomes a part of the procedures that must be performed to preserve the goods' quality in order to make it possible to store the products and prevent them from being damaged during the storing time in the warehouse (it should meet the minimum water level of $14 \%$ as required, for example). Malang Regency uses Surabaya Product Quality Testing and Certification Office (BPSMB) and Tobacco, Ujastama. Products like grain and cacao must be tested by the Quality Conformity Body before they can be stored in the warehouse.

\section{e. Credit Guarantee Institute}

Government has issued the Government Regulation No. 1 of 2016 concerning the Warehouse Receipt System Assurance Institute to protect banks. Article 2 mentions that the government assigns Public Corporation of Indonesian Credit

22 Suryani, E., Erwidodo, \& Anugerah, I. S, 2014, "Sistem Resi Gudang di Indonesia: Antara Harapan dan Kenyataan," Analisis Kebijakan Pertanian, 12 (1), p82.
Guarantee as the one implementing credit guarantee.

\section{Legal Culture Element}

Based on the study of facts in the field, the farmers still prefer the simple procedure with a more affordable fee. WRS law couldn't fulfill the farmers' needs. The complicated process of WRS causes farmers reluctant to use WRS. In its practice, using WRS is a loss for farmers since there is too much money to be spent; thus, less profit is gained. Some farmers even experienced a loss that caused trauma for using WRS to get credits in Bank. $^{23}$ The high expense and the long period needed for the Warehouse Receipt System in Malang make the farmers choose to get a direct payment rather than to keep the goods in the warehouse and wait for credits given by banks. Credit disbursement process couldn't be determined yet because the warehouse operator was not able to provide the certainty of warehouse receipt issuance time. ${ }^{24}$ The farmers hope that the credit process will only take seven days at maximum and will not have many procedures. 25 The same fact is also confronted by the farmers in Kuningan Regency who considered WRS procedure too sophisticated. ${ }^{26}$ The government's policy regarding People's Business Credit and

23 Nanik, Chief of KUD Tiga Roda Kecamatan Pakis Kabupaten Malang, interview, February 4, 2019.

24 Disperindag. Thursday, October 2, 2014. Meeting Report SKPD About WRS Implementation in Malang Region. Malang

25 Disperindag. March 2, 2016. Meeting Report SKPD About WRS Implementation in Malang Region. Malang

26 Bank Indonesia. Kajian Peningkatan Pemanfaatan Sistem Resi Gudang: Pilot Project di Kabupaten Kuningan, Jawa Barat (komoditas gabah) dan Konawe Selatan, Sulawesi Tenggara (komoditas kakao). July 2017, p80. 
Farmer Card which provide more ease than WRS adds more information to the fact.

A comprehensive evaluation of WRS in Malang Regency shows the loss experienced by all parties:

1. Farmers spent a high expense for transportation since the distance between warehouse and the farmers' paddy field is quite far because there is only one warehouse owned by the local government which obtained a license given by Commodity Futures Trading Regulatory Agency.

2. The local government paid the warehouse maintenance cost because the warehouse was left dysfunctional

3. The local government paid the assistance fee for warehouse operator candidates assistance program of Limited Liability Company of Pertani.

4. None of the warehouse operator candidates wanted to work as the warehouse operator because of the large warehouse maintenance operational cost.

Based on the study of the legal system, according to Friedman, the WRS law is still considered adequate. Besides substance, structure, and culture, Soerjono Soekanto added another element to the legal effectiveness theory namely 'means' as the legal effectiveness indicator. ${ }^{27}$ The WRS implementation in Indonesia, by considering the means provided by the government, was not adequate because the numbers of the warehouse are limited. One warehouse has still existed in Malang Regency, which is precisely located in Tumpang sub-district, that can even be utilized by the whole

27 Soerjono Soekanto, Faktor-Faktor yang Mempengaruhi Penegakan Hukum, Jakarta: PT. Raja Grafindo Persada, 2008, p8. farmers in 33 sub-districts. This fact is undoubtedly becoming an unfinished matter.

Roscoe Pound's social engineering concept is impressive balancing. He thinks that the most crucial element is the final goal of law that is implemented and leads the society to a better change. Rules must be made based on the needs of the community, must be able to solve problems and can fulfill the society's need. If a law cannot be an answer to a question, then this rule needs to be evaluated for a better change. ${ }^{28}$ WRS regulation should provide a balance in importance for the government, entrepreneur, and farmers. If WRS regulation aims to put the farmers in ease for obtaining financing access through a simple mechanism, but the goal has not been achieved during the implementation, then a change in law should be made. The Analysis above describes that the WRS regulation in Indonesia has not effectively implemented.

Law should follow the needs of the society. ${ }^{29}$ Satjipto Rahardjo agrees with the progressive law stating that law is always in the process of making (law as a process, legislation in the making). Law is not the final institution, but it is determined by its ability to serving human. Law needs to continuously construct and change itself into a better perfection level. ${ }^{30}$ WRS regulation should also take a role in its process of conforming itself with the farmers' need. The government is expected not to forcefully

28 Bernard L Tanya, Yoan N. Simanjutak, Markus Y. Hage, Teori Hukum (Strategi Tertib Manusia Lintas Ruang dan Generasi), Yogjakarta: Genta Publishing, 2010, pp154-165.

29 Darji Darmodihardjo, Sidharta, Pokok-Pokok Fisafat Hukum, Jakarta: Gramedia Pustaka Utama, 1999, p127.

30 Moh. Mahfud MD., Dkk, Dekontruksi dan Gerakan Pemikiran Hukum Progresif, Yogyakarta: Thafa Media, 2013. 
ensure that WRS regulation is the best choice. Farmers consider the WRS procedure as a sophisticated one, and there are other more accessible and simpler government policies.

Turki dan Indonesia confronts the same matter regarding the policy of the warehouse receipt system that is an investment in the warehouse receipt system that has a high-cost level. ${ }^{31}$ WRS problem is also confronted by Uganda that has managed Warehouse Receipt System since 2004, during its pilot, it failed to ensure market access and credit. ${ }^{32}$ WRS policy must always undergo an evaluation to accomplish the goal of the law in giving ease and benefit to farmers regarding the access in getting capital.

\section{CONCLUSION}

The result of the legal system analysis indicates that the WRS regulation was still not implemented effectively. The objectives of WRS to provide easy, affordable, and beneficial access for the farmers had not been met. The WRS regulation did not give any benefits to the farmers; instead, it caused a loss. The WRS regulation evaluation based on the theory of Friedman consisting of substance, structure, and culture has pointed out the significant numbers of problems during WRS implementation, including government infrastructure and societal culture (farmers). The government policy regarding the warehouse establishment in each regency and province

31 Duygu Tosun, Kerem Savran, Ozge Can Niyaz, Berkay Keskin, Nevin Demirbaş, 2014, "The Evaluation Of The Warehouse Receipt System For Agrofood Products In Turkey," Derleme Review, 29 (3), pp240-247

32 Miriam Katunze, Annette Kuteesa, Teresa Mijumbi, and Dennis Mahebe, 2017, "Uganda Warehousing Receipt System: Improving Market Performance and Productivity," African Development Review, 29 (S2), pp135-146 needs to be evaluated once more since there are many dysfunctional warehouses, and it spent the regional and central budget (warehouse maintenance expense) too much. Prominent businesspeople can only implement WRS; therefore, it is oriented for businesspeople whose businesses are related to useful export or wholesaler. To face the free trading program through ASEAN Economic Community, WRS regulation in Indonesia has not been able to help small farmers in providing affordable and easy access for credit program. The recommendations are, first, the government must make WRS regulation that can give advantage for small farmer. Second, the government must also integrate that regulation with the farmer policy.

\section{REFERENCES}

\section{Books}

Tanya, Bernard L., Yoan N. Simanjutak, Markus Y. Hage. 2010. Teori Hukum (Strategi Tertib Manusia Lintas Ruang dan Generasi). Yogjakarta: Genta Publishing.

Darmodihardjo, Darji., Sidharta. 1999. Pokok-Pokok Fisafat Hukum. Jakarta: Gramedia Pustaka Utama.

Disperindag. March 2, 2016. Meeting Report SKPD About WRS Implementation in Malang Region. Malang.

Djumhana, M. 2011. Hukum Perbankan di Indonesia. Bandung: Citra Aditya Bhakti.

Fajar, Mukti., dan Yulianto Achmad. 2010. Dualisme Penelitian Hukum Empiris \& Normatif. Yogyakarta: Pustaka Pelajar.

Friedman, Lawrence, M. 2013. Sistem Hukum Perspektif Ilmu Sosial, The Legal System: A Social Science Perspective. Bandung: Nusamedia. 
Hariyani, I., dan Servianto. 2010. Resi Gudang Sebagai Jaminan Kredit dan Alat Perdagangan. Jakarta: Sinar Grafika.

MD, Moh. Mahfud., Dkk. 2013. Dekontruksi dan Gerakan Pemikiran Hukum Progresif. Yogyakarta: Thafa Media.

Soebekti. 1986. Jaminan-Jaminan Untuk Pemberian Kredit Menurut Hukum Indonesia. Jakarta: Alumni.

\section{Journal}

Coulter, J., G. Onumah. 2002. "The Role of Warehouse Receipt Systems in Enhanced Commodity Marketing and Rural Livelihoods in Africa." Food Policy. 27(2002).

Fachruddin, Achmad., Lestari Rahayu. 2017. "Evaluasi Prasyarat Keberhasilan Sistem Resi Gudang di Kabupaten Bantul." https:// doi.org/10.18196/agr.3250. AGRARIS: Journal of Agribusiness and Rural Development Research. 3 (2).

Listiani, N., \& Haryotejo, B. 2013. "Implementasi Sistem Resi Gudang Pada Komoditi Jagung: Studi Kasus di Kabupaten Tuban, Provinsi Jawa Timur." Buletin Ilmiah Litbang. 7(2).

Mahanta, D. October 2012. "Review of Warehouse Receipt as An Instrument for Financing in India." International Journal of Scientific \& Technology Research. 1(9).

Katunze, Miriam., Annette Kuteesa, Teresa Mijumbi, and Dennis Mahebe. 2017. "Uganda Warehousing Receipt System: Improving Market Performance and Productivity." African Development Review, 29(S2).

Rina Oktaviani, dkk. 2017. "Kajian Peningkatan Pemanfaatan Sistem Resi Gudang: Pilot Project di Kabupaten Kuningan, Jawa Barat (Komoditas Gabah) dan Konawe Selatan, Sulawesi Tenggara (Komoditas Kakao)." Buku BI 4.
Suryani, E., Erwidodo,, \& Anugerah, I. S. 2014. "Sistem Resi Gudang di Indonesia: Antara Harapan dan Kenyataan." Analisis Kebijakan Pertanian. 12(1).

Tosun, Duygu., Kerem Savran, Ozge Can Niyaz, Berkay Keskin, Nevin Demirbas, 2014. "The Evaluation Of The Warehouse Receipt System For Agrofood Products In Turkey." Derleme Review. 29(3).

\section{World Wide Web}

Primartantyo, U. 2012. Penerapan Resi Gudang di Solo Tak Menguntungkan. Available from: http://www. tempo.co/read/news/ 2012/12/19/090449267/Penerapan-Resi-

Gudang-di-Solo-Tak-Menguntungkan. [retrieved: December 20, 2018].

KUR. Available From: http://kur.ekon.go.id/maksud-dan-tujuan.

[retrieved: December 25, 2018].

Wikipedia. 2019. Resi Gudang. Available From: https://id.wikipedia.org/wiki/Resi_gudang.

[retrieved: December 28, 2018].

\section{Newspaper}

Infobank News.com. 2013. Asuransi Ternak Sapi diharap Dongkrak Kredit Pertanian. October 23.

Bappebti/Mj1/190/XVI/2017/September Edition.

\section{Laws}

The 2006 Law No. 9 Concerning Warehouse Receipt System.

The 2011 Law No. 9 Concerning Amendment of Warehouse Receipt System.

The 1997 Law No. 32 Concerning Commodity Futures Trading.

The 2011 Law No. 10 Concerning Amendment of The 1997 Law No. 32 Concerning Commodity Futures Trading.

The 2007 Government Regulation, the Republic of Indonesia No. 36 on the Implementation of the 2006 Act No. 9 concerning Warehouse Receipt System. 
The 2016 Government Regulation of the Republic of Indonesia No. 9 Concerning The Guarantor of Warehouse Receipt System.

The 2007 Regulation of Ministry of Trade, the Republic of Indonesia No. 26 concerning Goods which can be Stored in Warehouse f WRS Management.

The 2018 Regulation of Ministry of Trade, the Republic of Indonesia No. 33 on the Third Amendment of Ministry of Trade Regulation No. 37/M-dag/Per/11/2011 concerning Goods which can be Stored in Warehouse of WRS Management.

The 1999 Presidential Decision, the Republic of Indonesia No. 12 concerning Commodity which can be Futures Contract Subject.
The 2000 Presidential Decision, the Republic of Indonesia No. 73 concerning Commodity which can be Futures Contract Subject.

The 2001 Presidential Decision, the Republic of Indonesia No. 119 concerning Commodity which can be Futures Contract Subject.

The 2007 Regulation of Bank Indonesia No. 9.

The Regulation of the Chief of the Supervisor Committee of Futures Commodity Trading No. 01/BAPPEBTI/PER-WRS/7/2007. 